\title{
Activation of mitogen-activated protein kinase pathways during the death of PC12 cells is dependent on the state of differentiation
}

\author{
Nathalie Lambeng ${ }^{\mathrm{a}, 1}$, Sandrine Willaime-Morawek ${ }^{\mathrm{b}, 1}$, Jean Mariani ${ }^{\mathrm{c}}$, Merle Ruberg ${ }^{\mathrm{a}}$, \\ Bernard Brugg ${ }^{\mathrm{b}, *}$
}

a'INSERM U.289, Hôpital de la Salpêtrière, 47 boulevard de l'Hôpital, 75013 Paris, France

${ }^{\mathrm{b}}$ Laboratoire Signalisation Neuronale et Régulation Génique, Unité Neurobiologie des Processus Adaptatifs (UMR 7102),

Université Pierre et Marie Curie, Bât. B $6^{e}$ étage, Case 12, 9 quai Saint Bernard, 75252 Paris CEDEX 05, France

${ }^{\mathrm{c}}$ Laboratoire Dévelopment et Vieillisement du Système Nerveuz, Unité Neurobilogie des Processus Adaptatifs (UMR 7102), Université Pierre et Marie Curie, 9 quai Saint Bernard, 75005 Paris, France

Accepted 3 December 2002

\begin{abstract}
PC12 cells that are differentiated with NGF and cAMP become totally dependent on these factors for their survival, unlike those that are differentiated with NGF alone. We have asked whether the MAP Kinases, ERKs, JNKs and p38s play a role in the cell death induced by withdrawal of trophic factors on NGF- and NGF/cAMP-differentiated PC12 cells. By Western-blot analyses with antibodies directed against the activated forms of these kinases, we show that when the trophic factors were withdrawn, ERK phosphorylation was reduced to very low levels within $1 \mathrm{~h}$ in both cases. Changes in the other enzymes were observed only in the NGF/cAMP-differentiated cells, in which the JNK phosphorylation increased about $160 \%$ by $6 \mathrm{~h}$ and that of p38 increased linearly to at least 18-fold throughout the cell death process. The increases in p38 and JNK phosphorylation were implicated in the death of the cells, since the p38 inhibitor PD169316 and the JNK inhibitor SP600125 were protective. These results demonstrate that the state of differentiation of PC12 cells, a model for the differentiation of sympathetic neurons, determines their vulnerability to cell death by modifying the state of phosphorylation and the regulation of specific kinases implicated in signal transduction pathways that are responsible for the survival or the death of these cells. (C) 2002 Elsevier Science B.V. All rights reserved.
\end{abstract}

Theme: Development and regeneration

Topic: Neuronal death

Keywords: cAMP; NGF; p38; ERK; JNK; MAPK; Trophic factor withdrawal.

\section{Introduction}

PC12 cells, derived from a rat pheochromocytoma [11], have been widely used to study the molecular events leading to neuronal differentiation. More recently, these

\footnotetext{
Abbreviations: ASK1, apoptosis signal-regulating kinase 1; BSA, bovine serum albumin; (db)cAMP, (dibutyryl) cyclic adenosine monophosphate; ERKs, extracellular signal-regulated kinases; JNKs, c-Jun $\mathrm{N}$-terminal kinases; MAP kinases, mitogen activated protein kinases; MEK, MAP kinase kinase; MTT, 3-(4,5-dimethylthiazol-2-yl)-2,5diphenyltetrazolium bromide; NGF, nerve growth factor

*Corresponding author. Tel.: +33-1-4427-3242; fax: +33-1-44272669.

E-mail address: bernard.brugg@snv.jussieu.fr (B. Brugg).

${ }^{1}$ These authors contributed equally to this paper.
}

cells, which acquire a neuronal phenotype in the presence of NGF, have been shown to constitute an interesting model for investigating the relationship between the state of differentiation and the susceptibility to apoptosis induced by trophic factor withdrawal $[21,22,27,29]$. In the presence of serum, PC12 cells divide and resemble precursors of adrenal chromaffin cells and sympathetic neurons [11]. When treated with serum and NGF, PC12 cells undergo reversible neuronal differentiation; if NGF and serum are removed from the culture medium, the cells die [22]. Chronic exposure of NGF-differentiated PC12 cells to a stable cell permeable analogue of cAMP potentiates their differentiation. The cell bodies become large, the neuritic arborization more elaborate and, most importantly, they become dependent on NGF or cAMP for their 
survival and die, rather than dedifferentiate, when these factors are withdrawn [22,27].

The molecular mechanisms involved in the switch that renders NGF/cAMP-differentiated PC12 cells more sensitive to trophic factor withdrawal are not clearly established. The MAP kinase cascades may, however, be expected to play an important role. These serine/threonine kinases mediate intracellular signal transduction and can be subdivided into three families (review in Refs. $[2,17,28,34])$. The extracellular signal-regulated kinases (ERKs) are activated by mitogens and growth factors and are mainly involved in cell proliferation and differentiation. The c-Jun N-terminal kinases (JNKs) and the p38 kinases are activated by proinflammatory cytokines, heat shock, hyperosmolarity and other cellular stresses, and seem to be preferentially implicated in apoptotic processes [20,23,38-40]. The MAP kinases have been shown to be differently regulated in NGF-differentiated PC12 cells during their death induced by NGF withdrawal [40]. Whereas the ERK pathway was inhibited, the JNK and p38 signaling pathways were activated, leading to apoptosis.

These results encouraged us to evaluate whether irreversible differentiation of $\mathrm{PC} 12$ cells with $\mathrm{NGF}$ and cAMP modifies the regulation of MAP kinases and their activation during cell death induced by trophic factor withdrawal. We show that ERK phosphorylation rapidly decreases following trophic factor withdrawal in both cell types. In addition, in NGF/cAMP-differentiated cells, the cell death process requires the phosphorylation of $\mathrm{p} 38 \mathrm{~s}$ and JNKs. The state of differentiation of the PC12 cells affects the way in which the cells die, and thus their vulnerability to death inducing stimuli.

\section{Materials and methods}

\subsection{Cell culture}

PC12 cells were maintained in RPMI 1640 culture medium (Gibco BRL, Gaitherburg, MD, USA) with 5\% horse serum (Eurobio, Les Ulis, France), $10 \%$ fetal calf serum (Eurobio, Les Ulis, France), $60 \mu \mathrm{g} / \mathrm{ml}$ penicillin-G and $100 \mu \mathrm{g} / \mathrm{ml}$ streptomycin in uncoated flasks. For differentiation, the cells were plated in polyethyleneiminecoated wells at a density of 1500 cells $/ \mathrm{cm}^{2}$ as described [22], and were maintained in L15 medium (Sigma, St. Louis, MO, USA) supplemented with $10 \%$ horse serum (Eurobio), 5\% fetal calf serum and other additives as in Ref. [19]. In order to induce differentiation, the cells were exposed to $150 \mathrm{ng} / \mathrm{ml} \mathrm{NGF} 2.5 \mathrm{~S}$ (Alomone Labs, Jerusalem, Israel). Concentrations were determined by dose-response analyses to produce optimal differentiation under our culture conditions (results not shown). After 7 days in the presence of NGF, the stable cell permeable cAMP analogue dibutyryl, dbcAMP $(500 \mu \mathrm{M})$ was added and differentiation continued for 4 days. During co-treat- ment with NGF and dbcAMP, culture medium was changed every 2 days.

For deprivation experiments, the differentiation medium was replaced on day 12 in vitro by the appropriate deprivation medium (see Section 3). Cell death was quantified to ensure that trophic factor withdrawal caused a $50 \%$ decrease in survival after 48 or $24 \mathrm{~h}$ in NGF- and NGF/cAMP-differentiated PC12 cells, respectively.

The following compounds were tested for their effects on survival: the MEK inhibitor PD98059 (Alexis Corporation), the p38 inhibitor PD169316 and the JNK inhibitor SP600125 (Calbiochem, La Jolla, CA, USA) used at concentrations (100, 5, and $50 \mu \mathrm{M}$, respectively) determined to be maximally effective (results not shown).

\subsection{Quantification of cell survival}

Cells were incubated for $30 \mathrm{~min}$ at $37^{\circ} \mathrm{C}$ with 250 $\mu \mathrm{g} / \mathrm{ml}$ MTT (3-(4,5-dimethylthiazol-2-yl)-2,5-diphenyltetrazolium bromide, Sigma). The total number of cells and the number of viable cells containing the MTT reaction product were counted under bright field illumination at $10 \times$ magnification, in 10-20 randomly chosen fields (Diaphot, Nikon), or the purple formazan salt was solubilized in $100 \mu \mathrm{l}$ of a solution containing $0.1 \mathrm{M} \mathrm{HCl}$ in isopropanol and quantified by spectrophotometry at 560 nm.

\subsection{Analyses of kinase activation}

\subsubsection{Antibodies}

We used New England Biolabs (Beverly, MA, USA) rabbit antisera specifically directed towards phospho$\mathrm{Thr}^{202}-\mathrm{Tyr}^{204}$ ERK1 (p44) diluted 1:2500, phospho$\mathrm{Thr}^{183}$-Tyr ${ }^{185}$ JNK diluted 1:1000, Phospho-Ser ${ }^{73}$ c-Jun diluted 1:500, phospho-Thr ${ }^{180}$-Tyr ${ }^{182}$ p38 diluted 1:200. We also used rabbit polyclonal antisera (New England Biolabs) raised against synthetic peptides specific for JNK diluted 1:1000 and for p38 diluted 1:1000, goat polyclonal antisera (Santa Cruz Biotechnology) raised against synthetic peptides specific for ERK2 diluted 1:4000.

\subsubsection{Western-blot analyses}

Cultured PC12 cells were lysed in solubilization buffer (10 mM Tris- $\mathrm{HCl}, 50 \mathrm{mM} \mathrm{NaCl}, 1 \%$ Triton $\mathrm{X}-100,30$ $\mathrm{mM} \mathrm{Na} \mathrm{P}_{2} \mathrm{O}_{7}, 50 \mathrm{mM} \mathrm{NaF}, 5 \mathrm{mM} \mathrm{ZnCl}, 100 \mathrm{mM}$ $\mathrm{Na}_{3} \mathrm{VO}_{4}, 1 \mathrm{mM}$ dithiothreitol, $5 \mathrm{nM}$ okadaic acid, 2.5 $\mathrm{mg} / \mathrm{ml}$ aprotinin, $3.6 \mathrm{mM}$ pepstatin, $0.5 \mathrm{mM}$ phenylmethylsulfonyl fluoride, $0.5 \mathrm{mM}$ benzamidine, $5.3 \mathrm{mM}$ leupeptin) at $4{ }^{\circ} \mathrm{C}$. Insoluble material was removed by centrifugation $\left(13000 \times g\right.$ for $20 \mathrm{~min}$ at $\left.4{ }^{\circ} \mathrm{C}\right)$ and samples were stored at $-80{ }^{\circ} \mathrm{C}$. The protein concentration was determined with the DC protein assay kit (Bio-Rad). Cellextracts containing equivalent amounts of protein were boiled for $5 \mathrm{~min}$ in sample loading buffer. After a $10 \%$ 
SDS-PAGE, proteins were transferred onto a polyvinylidene difluoride membrane (ICN Biochemicals). Nonspecific protein binding sites were blocked with $5 \%$ skimmed milk for $2 \mathrm{~h}$. Blots were then incubated overnight at $4{ }^{\circ} \mathrm{C}$ with primary antibodies against the phosphorylated form of the kinases, in 5\% BSA. They were then incubated with horseradish peroxidase-conjugated secondary antibodies in 5\% skimmed milk for $1 \mathrm{~h}$. Peroxidase activity was revealed with the enhanced chemiluminescence substrate (Amersham). The blots were then stripped with $0.1 \mathrm{M}$ glycine- $\mathrm{HCl}(\mathrm{pH} 2.8)$ twice for $30 \mathrm{~min}$ at $60{ }^{\circ} \mathrm{C}$ and SDS $2 \%$ for $10 \mathrm{~min}$, followed by saturation in $5 \%$ skimmed milk overnight at $4{ }^{\circ} \mathrm{C}$, then incubation with the primary antibody that recognizes both the phosphorylated and the non-phosphorylated forms of the kinases, in 5\% skimmed milk. They were then incubated with secondary antibodies. The activity was revealed as described above. The results were quantified on the photographic films by densitometry using Densylab software (Microvision Instruments). The results are expressed as the ratio of the phosphorylated kinase to total kinase immunoreactivity (normalized Pkinase activity).

\subsubsection{Immunocytochemistry analyses}

Cultured PC12 were fixed with PBS containing 4\% paraformaldehyde for $20 \mathrm{~min}$ and then incubated with methanol/acetone solution $(50: 50, \mathrm{v} / \mathrm{v})$ for $10 \mathrm{~min}$ at $4{ }^{\circ} \mathrm{C}$. After three washes in PBS, the plates were treated with permeabilisation buffer containing Triton X-100 $0.2 \%$ in PBS for $15 \mathrm{~min}$ and blocking buffer containing fetal calf serum $10 \%$, bovine serum albumin $3 \%$ in PBS for $30 \mathrm{~min}$. Polyclonal antibodies raised against Phospho-c-Jun (Ser ${ }^{73}$ c-Jun) (P-c-Jun, 1:500, New England Biolabs) were incubated overnight at $4{ }^{\circ} \mathrm{C}$ in PBS containing $1 \%$ BSA, $0.2 \%$ Triton $\mathrm{X}-100$. The plates were then rinsed in PBS and incubated with an anti-rabbit $\mathrm{Cy} 3$ conjugated antibody (1:2000, Sigma) for $2 \mathrm{~h}$ and counterstained with bisbenzimide.

\section{Results}

\section{1. p38 phosphorylation is down-regulated during irreversible differentiation of NGF-differentiated PC12 cells with $c A M P$}

To follow kinase activation, cellular extracts of NGFand NGF/cAMP-differentiated PC12 cells were subjected to Western-blot analyses, using antibodies directed against the activated forms of the MAP kinases and against the total MAP kinases regardless of their phosphorylation state. The basal levels of phosphorylation of the ERKs, JNKs and p38s in PC12 cells differentiated by NGF or NGF/cAMP are shown in Fig. 1. In comparison with differentiation by NGF alone, treatment of NGF-differentiated PC12 cells with cAMP for an additional 4 days caused a substantial decrease in p38 phosphorylation (Fig. 1C), without significantly affecting the level of P-ERKs and P-JNKs (Fig. 1A,B). Normalized P-p38 immunoreactivity decreased upon irreversible differentiation with cAMP and reached $32 \pm 10 \%$ of the value obtained for PC12 cells differentiated 1 week with NGF alone (Fig. $1 \mathrm{C})$.

\subsection{Trophic factor withdrawal induces a rapid decrease of P-ERK in both types of PC12 cells}

As we previously showed [22], NGF-differentiated PC12 cells die when NGF and serum are withdrawn from the culture media, whereas NGF/cAMP-differentiated cells die, even in the presence of serum, if both NGF and cAMP are withdrawn. To determine whether the state of differentiation of the PC12 cells modulates ERKs, JNKs or p38s during trophic factor withdrawal, we analyzed their state of phosphorylation by Western-blotting. Our results showed a rapid decrease in normalized P-p44 and P-p42 immunoreactivity, in both NGF- and NGF/cAMP-differentiated PC12 cells (Fig. 2A,B). The decrease in the level of phosphorylation of p44 and p42 was detected as early as $30 \mathrm{~min}$ after trophic factor withdrawal and, at $1 \mathrm{~h}$, the values reached, respectively, $14.7 \pm 4.2$ and $2.7 \pm 1.3 \%$ of control values in NGF-differentiated PC12 cells and $24.4 \pm 6.8$ and $14.6 \pm 2.2 \%$ in NGF/cAMP-differentiated PC12 cells. In both cell types, the phosphorylation levels of p44 and p42 remained low throughout the cell death process.

To determine whether the decrease in ERK phosphorylation was responsible for the cell death observed after trophic factor withdrawal, we mimicked ERK downregulation with PD98059 that inhibits MEK, the MAP kinase kinase responsible for ERK phosphorylation [5]. PD98059 inhibition of ERK phosphorylation had only a minimal effect on the survival of NGF-differentiated PC12 cells (Fig. 2C) and no effect on the survival of NGF/cAMPdifferentiated cells (Fig. 2D). Furthermore, it did not modulate the effect of trophic factor withdrawal on survival (Fig. 2C,D).

\subsection{JNK is only activated during the death of NGF/ cAMP-differentiated PC12 cells and its inhibition prevents cell death}

Western-blot analyses of JNK activation after trophic factor withdrawal showed that removal of NGF/serum from NGF-differentiated PC12 cells did not affect P-p54 and P-p46 levels (Fig. 3A). However, P-p54 and P-p46 both increased during NGF/cAMP withdrawal in NGF/ cAMP-differentiated PC12 cells (Fig. 3B). This increase reached $165 \%$ at $16 \mathrm{~h}$ for $\mathrm{P}-\mathrm{p} 54$, and $189 \%$ at $16 \mathrm{~h}$ for P-p46. 
A

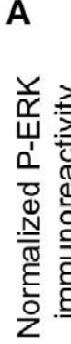

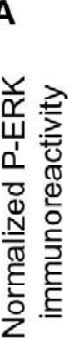

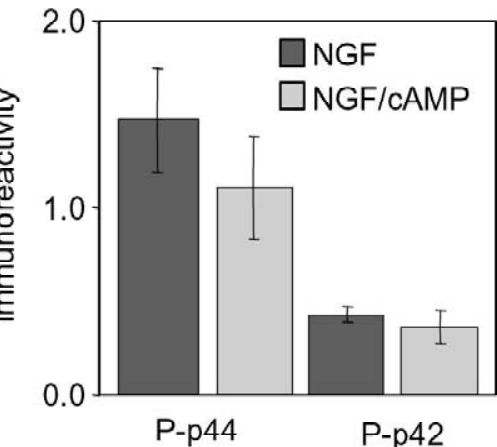

B
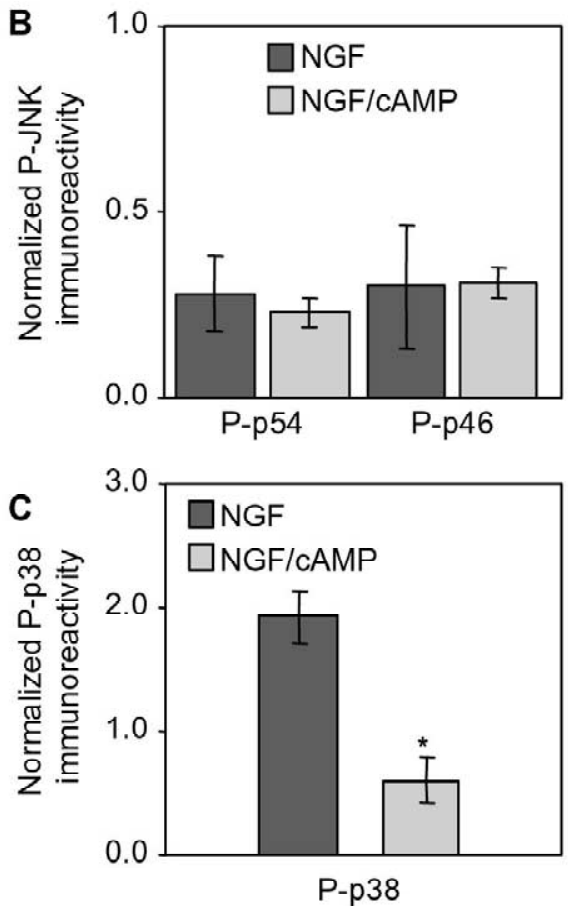

D

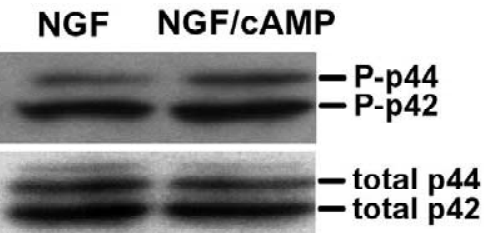

E

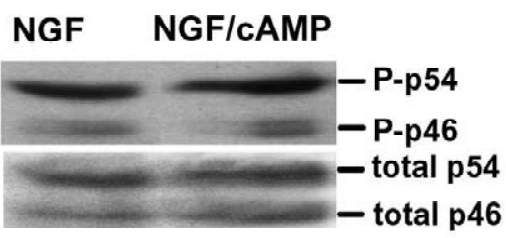

$F$

\section{NGF NGF/cAMP}

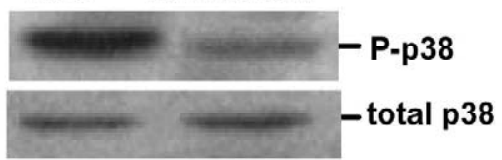

Fig. 1. Effect of chronic cAMP treatment on PC12 cells on the MAP kinases. Western-blot analyses and quantification of P-ERK (P-p44 and P-p42) and total ERK(total p44 and total p42) (A), P-JNK (P-p54 and P-p46) and total JNK (total p54 and total p46) (B) and P-p38 and total p38 (C) in extracts of both NGF- and NGF/cAMP-differentiated PC12 cells. NGF- and NGF/cAMP-differentiated cells were analyzed on the same gel. Normalized P-MAPK signals are the ratio of P-MAPK to total MAPK. Data represent the mean \pm S.E.M. of three independent experiments. * Significantly different from NGF-differentiated PC12 cells $(P<0.05$, Student's $t$-test). The immunoblots shown in D-F are from representative experiments.

To determine whether the increase in JNK phosphorylation was required for the cell death induced by trophic factor withdrawal in NGF/cAMP-differentiated PC12 cells, we inhibited the activity of this kinase with SP600125 [1,13]. To test this new inhibitor in differentiated PC12 cells, we performed an immunocytochemical study of c-Jun phosphorylated on serine 63 (Fig. 4A-C, E-G). We show that at $50 \mu \mathrm{M}$, SP600125 inhibited c-Jun phosphorylation induced by $16 \mathrm{~h}$ of NGF/cAMP withdrawal. In addition, SP600125 completely inhibited cell death in NGF/cAMP-differentiated PC12 cells quantified $24 \mathrm{~h}$ after trophic factor withdrawal (Fig. 4I), showing that irreversible differentiation of $\mathrm{PC} 12$ cells with cAMP in addition of NGF results in a modification of the cell death signal transduction pathway to include activation of JNK.

\section{4. p38 is only activated during the death of NGF/} cAMP-differentiated PC12 cells and its inhibition prevents cell death

We then analysed the kinetics of p38 phosphorylation during the death of NGF- and NGF/cAMP-differentiated PC12 cells (Fig. 5A). No significant change in P-p38 levels was observed in NGF-differentiated cells deprived of NGF and serum. However, the withdrawal of NGF/cAMP from the culture medium of NGF/cAMP-differentiated cells 

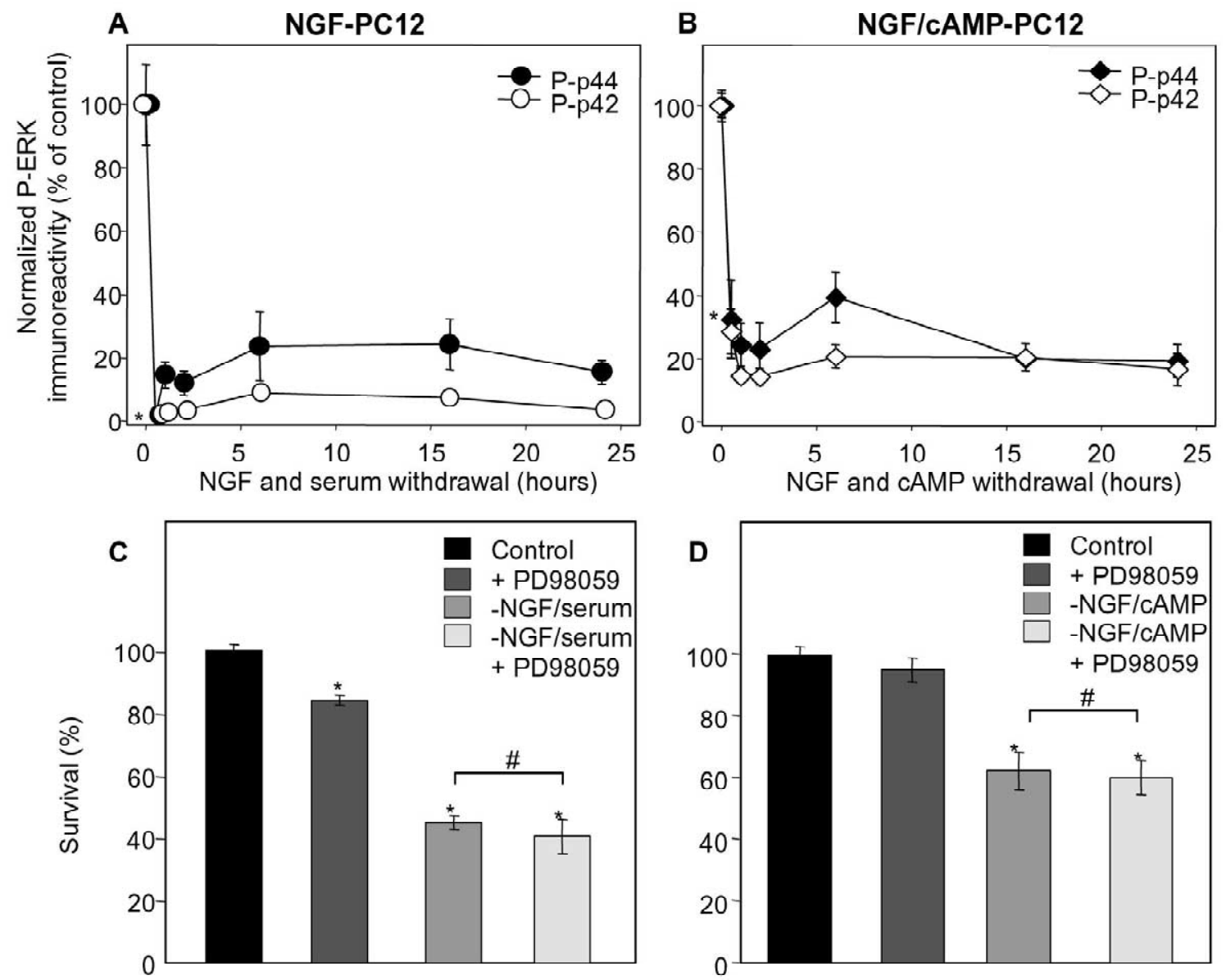

Fig. 2. Withdrawal of trophic factors induces a decrease in ERK phosphorylation in both NGF- and NGF/cAMP-differentiated PC12 cells. Quantification of Western-blot analyses of P-ERKs and total ERKs in extracts of NGF-differentiated PC12 cells deprived of NGF and serum (A) or NGF/cAMPdifferentiated PC12 cells deprived of NGF and cAMP (B). P-ERK signals were normalized to the corresponding total ERK signal and the percent difference with respect to controls was calculated (P-p44 and P-p42). Data represent the mean \pm S.E.M. of three independent experiments. All the points are significantly different from the control. * First time point significantly different from the control value $(P<0.05$, one-way ANOVA followed by Dunnett's test). (C,D) Effect of the MEK inhibitor PD98059 on survival after trophic factor withdrawal. Survival was assessed using the MTT assay on control cells or after $48 \mathrm{~h}$ of NGF/serum withdrawal (C) or $24 \mathrm{~h}$ of NGF/cAMP withdrawal (D) with or without PD98059 (100 $\mu \mathrm{M})$ treatment. Data represent the mean \pm S.E.M. of three independent experiments, each performed in triplicate. * Significantly different from the control value $(P<0.05$, one-way ANOVA followed by Dunnett's test). "Values are not significantly different from each others.

induced a strong increase in p38 phosphorylation. This up-regulation began as early as 30 min after the treatment and reached 18 -fold at $24 \mathrm{~h}$.

To determine whether the increase in p38 phosphorylation was involved in the cell death induced by trophic factor withdrawal in NGF/cAMP-differentiated PC12 cells, we inhibited the activity of this kinase with PD169316 [20]. At $5 \mu \mathrm{M}$, PD169316 completely inhibited cell death in NGF/cAMP-differentiated PC12 cells quantified $24 \mathrm{~h}$ after trophic factor withdrawal (Fig. 5B). To test whether this inhibitor also affected the JNK/c-Jun pathway in differentiated PC12 cells, we performed an immunocytochemical study of c-Jun phosphorylated on serine 63 (Fig. 4D-H). We show that at $5 \mu \mathrm{M}$, PD169316 did not inhibit c-Jun phosphorylation induced by $16 \mathrm{~h}$ of
NGF/cAMP withdrawal and can be considered specific for p38. This shows, as for JNK, that after irreversible differentiation of PC12 cells, p38 activation becomes part of the cell death signal transduction pathway.

\section{Discussion}

Although PC12 cells are commonly used to study the mechanisms of apoptosis induced by trophic factor withdrawal, the molecular link between their neuronal differentiation and their differential susceptibility to loss of trophic support remains unclear. In this study, we found that the basal state of ERK, JNK and p38 activation differed depending on whether the cells were reversibly differen- 


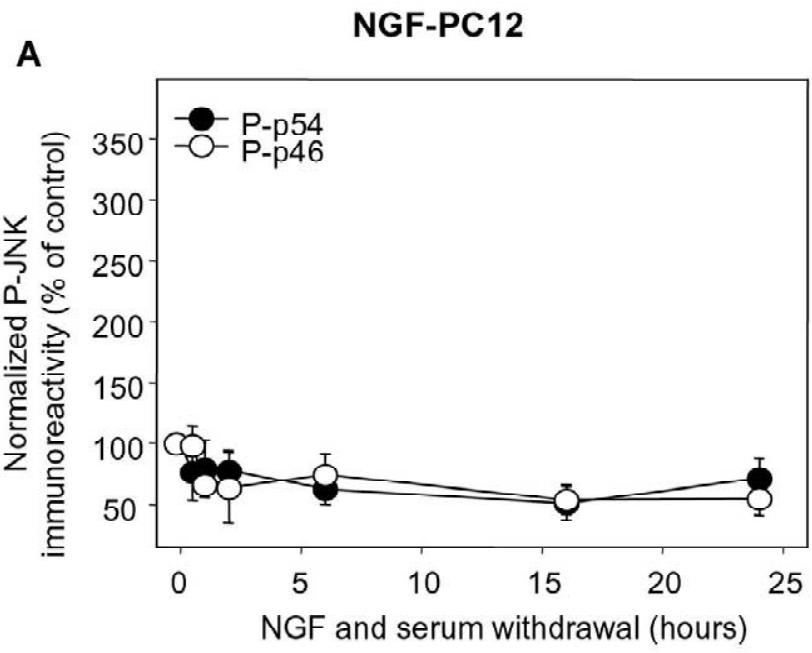

B

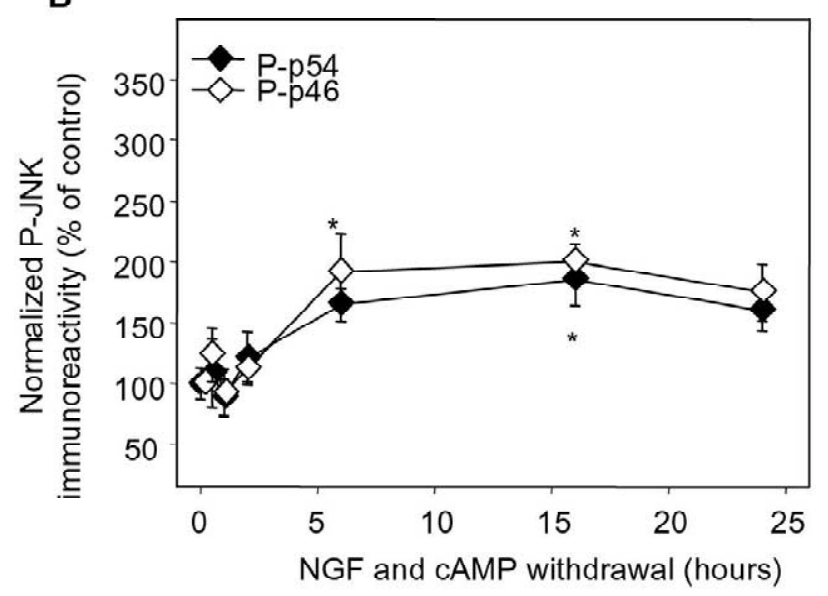

Fig. 3. Withdrawal of trophic factors induces an increase of JNK phosphorylation only in NGF/cAMP-differentiated PC12 cells. Quantification of Western-blot analyses of P-JNKs and total JNKs in extracts of NGF-differentiated PC12 cells deprived of NGF and serum (A) or NGF/cAMP-differentiated PC12 cells deprived of NGF and cAMP (B). P-JNK signals were normalized to the corresponding total JNK signal and the percent difference with respect to controls was calculated (P-p54 and P-p46). Data represent the mean \pm S.E.M. of three independent experiments. * Time point significantly different from control value $(P<0.05$, one-way ANOVA followed by Dunnett's test).

tiated with NGF alone or irreversibly differentiated with NGF and cAMP. As in our study, others have also shown that $\mathrm{p} 38$ activation by growth factor is inhibited by cAMP [14], but cAMP can also activate p38s during neuronal differentiation of PC12 cells [25].

We found that trophic factor withdrawal results in a large and rapid decrease in ERK phosphorylation in both NGF- and NGF/cAMP-differentiated cells, suggesting that chronic treatment with cAMP does not regulate the ERK pathway. Inhibition of ERK phosphorylation neither reproduced nor increased the effect of trophic factor withdrawal on survival. These results exclude a role for the
ERK pathway in the death of both reversibly and irreversibly differentiated PC12 cells.

Unlike the effects of trophic factor withdrawal on the ERKs, which were independent of the state of differentiation, JNK and p38 phosphorylation was observed after trophic factor withdrawal only in NGF/cAMP-differentiated cells. These results are consistent with the effects of trophic factor withdrawal in mature neurons, such as cerebellar granule neurons [36], sympathetic neurons $[7,24,35]$, and cortical neurons $[38,39]$. Activation of JNKs has also been reported to occur after NGF deprivation in PC12 cells $[23,24,31,40]$, under culture and differentiation conditions that differed from ours.

Withdrawal of NGF and cAMP resulted in a moderate increase in JNK phosphorylation. This apparently small activation could be due to dilution in whole cell homogenates of activated nuclear JNKs, as suggested by Coffey et al. [3]. SP600125, a pharmacological inhibitor of JNK, totally prevented the cell death induced by trophic factor withdrawal, highlighting the crucial role of this kinase in the cell death process. A requirement for JNK activation during cell death has also been described in other models, such as PC12 cells [40] and sympathetic neurons [12] deprived of NGF or cortical neurons treated with ceramide [39].

Withdrawal of NGF and cAMP resulted in a large and linear increase of p38 phosphorylation. PD169316, a pharmacological inhibitor of p38, totally prevented the cell death induced by trophic factor withdrawal, highlighting the crucial role of this kinase in the cell death process. As shown here and in several publications, this inhibitor of p38 is specific and does not affect ERK or JNK/c-Jun pathways $[9,20]$. Activation of p38 kinase during cell death has also been described in other models, such as cortical neurons treated with ceramide [38] or chick neurons deprived of trophic factors [16].

Since both p38s and JNKs are phosphorylated after trophic factor withdrawal in our NGF/cAMP-differentiated PC12 cells, it would be particularly interesting to determine whether the protein kinase ASK1, that is reported to activate JNKs in NGF-differentiated PC12 cells [18], is responsible for the activation of $\mathrm{p} 38 \mathrm{~s}$ and JNKs in our model of cell death. Overexpression of this kinase is indeed reported to induce death in NGF-differentiated PC12 cells and in primary rat sympathetic neurons, and its down-regulation has been reported to reduce the neuronal death caused by NGF withdrawal [18].

The downstream signaling events that couple p38 activation with neuronal cell death are still poorly understood. Recent data have shown that monoamine oxidase is upregulated by $\mathrm{p} 38$ kinase and participates in cell death induced by NGF withdrawal in PC12 cells [4]. The effect of p38s may also be mediated by apoptotic effectors such as Bid which is cleaved upon p38 activation [41] or Bax, the activation of which and its translocation to mitochondria have been shown to be regulated by p38s [10]. 

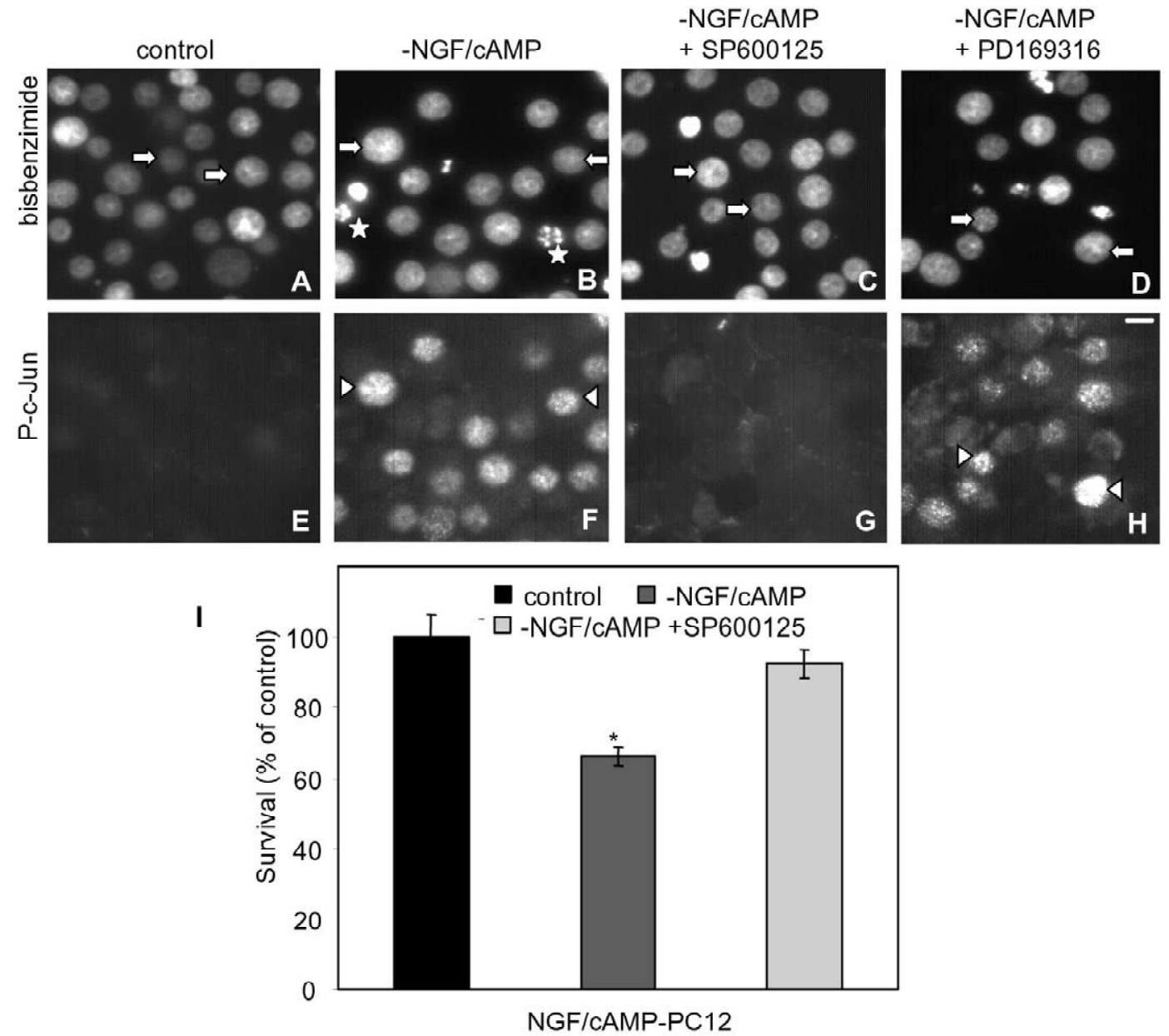

Fig. 4. Inhibition of JNK by SP600125 protects terminally-differentiated PC12 cells against cell death induced by trophic factor withdrawal. (A-H) The JNK inhibitor SP600125 inhibits c-Jun phosphorylation on residue serine 63 induced by NGF/cAMP withdrawal. PC12 cell nuclei labeled with bisbenzimide (A-D) and immunostained for P-c-Jun (E-H). NGF/cAMP-differentiated PC12 cells control (A,E), deprived of NGF/cAMP during 16 h $(\mathrm{B}, \mathrm{C}, \mathrm{D}, \mathrm{F}, \mathrm{G}, \mathrm{H})$ and treated with the JNK inhibitor SP600125 (50 $\mu \mathrm{M} ; \mathrm{C}, \mathrm{G})$ or the p38 inhibitor PD169316 (5 $\mu \mathrm{M}$; D,H). White arrows, normal nuclei; arrowheads, corresponding P-c-Jun labeling; stars, condensed and fragmented nuclei. Scale bar: $10 \mu \mathrm{M}$. (I) The JNK inhibitor SP600125 prevents phosphorylation of c-Jun and protects NGF/cAMP-differentiated PC12 cells from cell death induced by NGF and cAMP withdrawal. Survival was assessed after $24 \mathrm{~h}$ of NGF and cAMP withdrawal from NGF/cAMP-differentiated cells, in the presence or absence of SP600125 (50 $\mu$ M). Each bar represents the mean \pm S.E.M. of 12 wells from two independent experiments. ${ }^{*}$ Significantly different from control cells $(P<0.0001$, Student's $t$-test).

Cyclic AMP inhibits the redistribution of Bax to the mitochondria and the resulting loss of cytochrome $\mathrm{c}$ when sympathetic neurons are deprived of NGF, thus preventing cell death [32]. One might therefore speculate that cAMP exerts these effects through inhibition of the p38 kinases, and that NGF/cAMP withdrawal induces Bax translocation and activation via p38s.

The pro-apoptotic action of JNK pathway in NGF/ cAMP withdrawal may be mediated by apoptotic effectors such as Fas-Ligand the expression of which is regulated by JNK [15,30]; the Fas-Ligand promoter contains an AP-1 site that is a known target of the JNK pathway [8]. Bim, a pro-apoptotic member of Bcl-2 family, which is strongly induced in sympathetic neurons after NGF withdrawal, has also been shown to be under the transcriptional control of the JNK pathway $[33,37]$.

In conclusion, in this study we showed for the first time that, in NGF/cAMP-differentiated PC12 cells that reproduce the terminal phase of differentiation of sympathetic neurons, cell death induced by NGF/cAMP withdrawal involves a balance between the MAP kinase pathways: inhibition of ERK and activation of both JNK and p38 pathways. These results are in accordance with the pattern of regulation observed in cortical neurons treated by ceramide [38]. The present study highlights the crucial role of p38s and JNKs in the regulation of cell death induced by trophic factor withdrawal in NGF/cAMPdifferentiated PC12 cells. This effect might quite possibly be mediated through AP1 that is targeted by both the JNK substrate c-Jun and the p38 substrate ATF2. Additional investigations are needed to define the precise mechanisms by which cAMP regulates p38 phosphorylation, and the p38 isoforms involved. It would also be interesting to determine whether the trophic effect of cAMP in PC12 

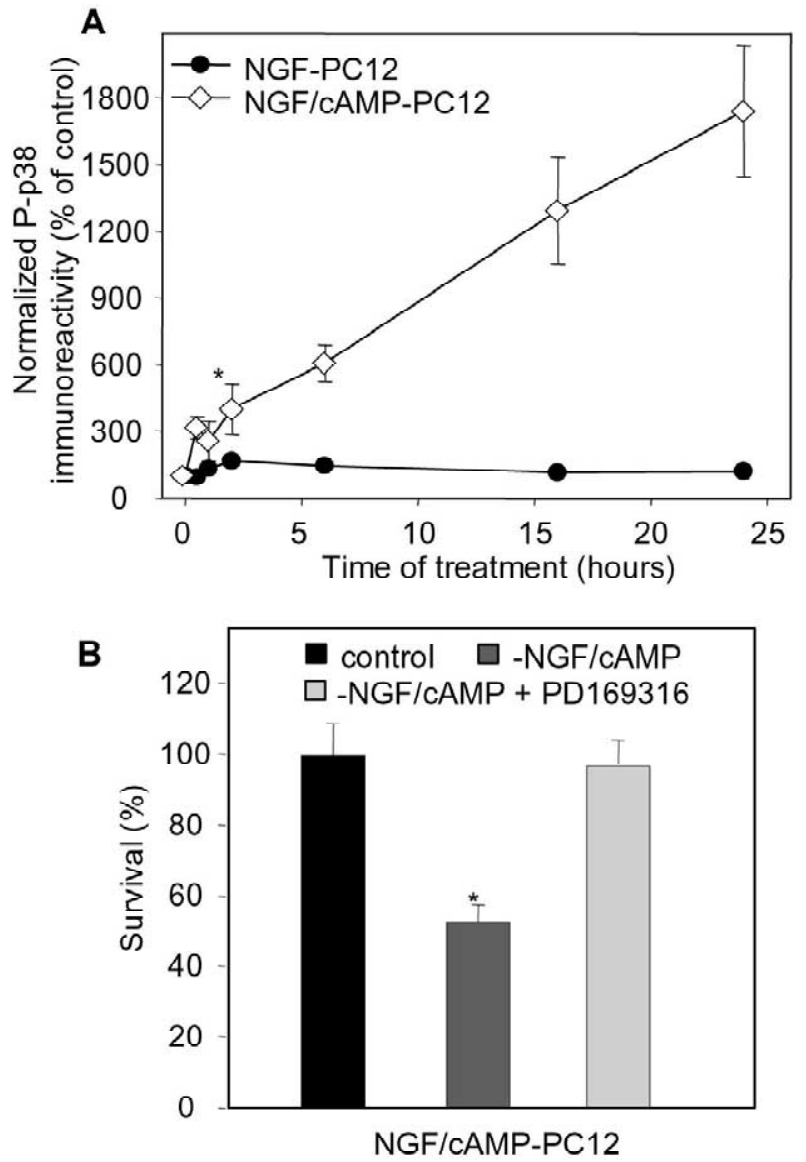

Fig. 5. Inhibition of p38 by PD169316 protects terminally-differentiated PC12 cells against cell death induced by trophic factor withdrawal. Quantification of Western-blot analyses of P-p38 and total p38 in extracts of NGF-differentiated PC12 cells deprived of NGF and serum or NGF/ cAMP-differentiated PC12 cells deprived of NGF and cAMP. Results are expressed as in Fig. 2. Data represent the mean \pm S.E.M. of three independent experiments. All the points from NGF/cAMP-differentiated PC12 cells are significantly different from the control. * First time point significantly different from the control value $(P<0.05$, one-way ANOVA followed by Dunnett's test). (B) The p38 inhibitor PD169316 (5 $\mu \mathrm{M})$ protects NGF/cAMP-differentiated PC12 cells from cell death induced by NGF and cAMP withdrawal. Survival was assessed after $24 \mathrm{~h}$ of NGF and cAMP withdrawal from NGF/cAMP-differentiated cells, in the presence or absence of PD169316 $(5 \mu \mathrm{M})$. Each bar represents the mean \pm S.E.M. of 20 wells from two independent experiments. * Significantly different from control cells $(P<0.001$, Student's $t$-test).

cells $[21,22]$ or in other neuronal models such as mesencephalic dopaminergic neurons [26] or sympathetic neurons $[6,32]$ is mediated through inhibition of the p38 kinase and/or JNKs.

\section{Acknowledgements}

This work was partially supported by grants from INSERM, the Association pour la Recherche sur le Cancer (to NL and SWM) and European Community (TMR
Neuril no. FMRX CT97-0149 and Biomed Cybrainet no. BMH4 CT97-2492 to JM).

\section{References}

[1] B.L. Bennett, D.T. Sasaki, B.W. Murray, E.C. O'Leary, S.T. Sakata, W. Xu, J.C. Leisten, A. Motiwala, S. Pierce, Y. Satoh, S.S. Bhagwat, A.M. Manning, D.W. Anderson, SP600125, an anthrapyrazolone inhibitor of Jun N-terminal kinase, Proc. Natl. Acad. Sci. USA 98 (2001) 13681-13686.

[2] E. Cano, L.C. Mahadevan, Parallel signal processing among mammalian MAPKs, Trends Biochem. Sci. 20 (1995) 117-122.

[3] E.T. Coffey, V. Hongisto, M. Dickens, R.J. Davis, M.J. Courtney, Dual roles for c-Jun N-terminal kinase in developmental and stress responses in cerebellar granule neurons, J. Neurosci. 20 (2000) $7602-7613$.

[4] G.S. De Zutter, R.J. Davis, Pro-apoptotic gene expression mediated by the p38 mitogen-activated protein kinase signal transduction pathway, Proc. Natl. Acad. Sci. USA 98 (2001) 6168-6173.

[5] D.T. Dudley, L. Pang, S.J. Decker, A.J. Bridges, A.R. Saltiel, A synthetic inhibitor of the mitogen-activated protein kinase cascade, Proc. Natl. Acad. Sci. USA 92 (1995) 7686-7689.

[6] S.N. Edwards, A.E. Buckmaster, A.M. Tolkovsky, The death programme in cultured sympathetic neurones can be suppressed at the posttranslational level by nerve growth factor, cyclic AMP, and depolarization, J. Neurochem. 57 (1991) 2140-2143.

[7] A. Eilers, J. Whitfield, C. Babij, L.L. Rubin, J. Ham, Role of the Jun kinase pathway in the regulation of c-Jun expression and apoptosis in sympathetic neurons, J. Neurosci. 18 (1998) 1713-1724.

[8] M. Faris, N. Kokot, K. Latinis, S. Kasibhatla, D.R. Green, G.A. Koretzky, A. Nel, The c-Jun N-terminal kinase cascade plays a role in stress-induced apoptosis in Jurkat cells by up-regulating Fas ligand expression, J. Immunol. 160 (1998) 134-144.

[9] T.F. Gallagher, G.L. Seibel, S. Kassis, J.T. Laydon, M.J. Blumenthal, J.C. Lee, D. Lee, J.C. Boehm, S.M. Fier-Thompson, J.W. Abt, M.E. Soreson, J.M. Smietana, R.F. Hall, R.S. Garigipati, P.E. Bender, K.F. Erhard, A.J. Krog, G.A. Hofmann, P.L. Sheldrake, P.C. McDonnell, S. Kumar, P.R. Young, J.L. Adams, Regulation of stress-induced cytokine production by pyridinylimidazoles; inhibition of CSBP kinase, Bioorg. Med. Chem. 5 (1997) 49-64.

[10] S. Ghatan, S. Larner, Y. Kinoshita, M. Hetman, L. Patel, Z. Xia, R.J. Youle, R.S. Morrison, p38 MAP kinase mediates bax translocation in nitric oxide-induced apoptosis in neurons, J. Cell Biol. 150 (2000) 335-347.

[11] L.A. Greene, A.S. Tischler, Establishment of a noradrenergic clonal line of rat adrenal pheochromocytoma cells which respond to nerve growth factor, Proc. Natl. Acad. Sci. USA 73 (1976) 2424-2428.

[12] J. Ham, C. Babij, J. Whitfield, C.M. Pfarr, D. Lallemand, M. Yaniv, L.L. Rubin, A c-Jun dominant negative mutant protects sympathetic neurons against programmed cell death, Neuron 14 (1995) 927-939.

[13] Z. Han, D.L. Boyle, L. Chang, B. Bennett, M. Karin, L. Yang, A.M. Manning, G.S. Firestein, c-Jun N-terminal kinase is required for metalloproteinase expression and joint destruction in inflammatory arthritis, J. Clin. Invest. 108 (2001) 73-81.

[14] T.O. Hansen, J.F. Rehfeld, F.C. Nielsen, Cyclic AMP-induced neuronal differentiation via activation of $\mathrm{p} 38$ mitogen-activated protein kinase, J. Neurochem. 75 (2000) 1870-1877.

[15] T. Herdegen, F.X. Claret, T. Kallunki, A. Martin-Villalba, C. Winter, T. Hunter, M. Karin, Lasting N-terminal phosphorylation of c-Jun and activation of c-Jun N-terminal kinases after neuronal injury, $\mathrm{J}$. Neurosci. 18 (1998) 5124-5135.

[16] S. Horstmann, P.J. Kahle, G.D. Borasio, Inhibitors of p38 mitogenactivated protein kinase promote neuronal survival in vitro, J. Neurosci. Res. 52 (1998) 483-490. 
[17] Y.T. Ip, R.J. Davis, Signal transduction by the c-Jun N-terminal kinase (JNK) - from inflammation to development, Curr. Opin. Cell. Biol. 10 (1998) 205-219.

[18] T. Kanamoto, M. Mota, K. Takeda, L.L. Rubin, K. Miyazono, H. Ichijo, C.E. Bazenet, Role of apoptosis signal-regulating kinase in regulation of the c-Jun N-terminal kinase pathway and apoptosis in sympathetic neurons, Mol. Cell. Biol. 20 (2000) 196-204.

[19] B. Knusel, P.P. Michel, J.S. Schwaber, F. Hefti, Selective and nonselective stimulation of central cholinergic and dopaminergic development in vitro by nerve growth factor, basic fibroblast growth factor, epidermal growth factor, insulin and the insulin-like growth factors I and II, J. Neurosci. 10 (1990) 558-570.

[20] J.L. Kummer, P.K. Rao, K.A. Heidenreich, Apoptosis induced by withdrawal of trophic factors is mediated by $\mathrm{p} 38$ mitogen-activated protein kinase, J. Biol. Chem. 272 (1997) 20490-20494.

[21] N. Lambeng, P.P. Michel, Y. Agid, M. Ruberg, The relationship between differentiation and survival in $\mathrm{PC} 12$ cells treated with cyclic adenosine monophosphate in the presence of epidermal growth factor or nerve growth factor, Neurosci. Lett. 297 (2001) 133-136.

[22] N. Lambeng, P.P. Michel, B. Brugg, Y. Agid, M. Ruberg, Mechanisms of apoptosis in PC12 cells irreversibly differentiated with nerve growth factor and cyclic AMP, Brain Res. 821 (1999) 60-68.

[23] H. Le-Niculescu, E. Bonfoco, Y. Kasuya, F.X. Claret, D.R. Green, M. Karin, Withdrawal of survival factors results in activation of the JNK pathway in neuronal cells leading to Fas ligand induction and cell death, Mol. Cell. Biol. 19 (1999) 751-763.

[24] A.C. Maroney, J.P. Finn, D. Bozyczko-Coyne, T.M. O'Kane, N.T. Neff, A.M. Tolkovsky, D.S. Park, C.Y. Yan, C.M. Troy, L.A. Greene, CEP-1347 (KT7515), an inhibitor of JNK activation, rescues sympathetic neurons and neuronally differentiated PC12 cells from death evoked by three distinct insults, J. Neurochem. 73 (1999) 1901-1912.

[25] L.J. McCawley, S. Li, M. Benavidez, J. Halbleib, E.V. Wattenberg, L.G. Hudson, Elevation of intracellular cAMP inhibits growth factor-mediated matrix metalloproteinase- 9 induction and keratinocyte migration, Mol. Pharmacol. 58 (2000) 145-151.

[26] P.P. Michel, Y. Agid, Chronic activation of the cyclic AMP signaling pathway promotes development and long-term survival of mesencephalic dopaminergic neurons, J. Neurochem. 67 (1996) 1633-1642.

[27] P.P. Michel, S. Vyas, Y. Agid, Synergistic differentiation by chronic exposure to cyclic AMP and nerve growth factor renders rat phaeochromocytoma PC12 cells totally dependent upon trophic support for survival, Eur. J. Neurosci. 7 (1995) 251-260.

[28] K. Mielke, T. Herdegen, JNK and p38 stresskinases-degenerative effectors of signal-transduction cascades in the nervous system, Prog. Neurobiol. 61 (2000) 45-60.

[29] K. Mielke, T. Herdegen, Fatal shift of signal transduction is an integral part of neuronal differentiation: JNKs realize TNFalphamediated apoptosis in neuronlike, but not naive, PC12 cells, Mol. Cell. Neurosci. 20 (2002) 211-224.
[30] Y. Morishima, Y. Gotoh, J. Zieg, T. Barrett, H. Takano, R. Flavell, R.J. Davis, Y. Shirasaki, M.E. Greenberg, Beta-amyloid induces neuronal apoptosis via a mechanism that involves the c-Jun $\mathrm{N}$ terminal kinase pathway and the induction of Fas ligand, J. Neurosci. 21 (2001) 7551-7560.

[31] D.S. Park, L. Stefanis, C.Y. Yan, S.E. Farinelli, L.A. Greene, Ordering the cell death pathway. Differential effects of BCL2, an interleukin-1-converting enzyme family protease inhibitor, and other survival agents on JNK activation in serum/nerve growth factordeprived PC12 cells, J. Biol. Chem. 271 (1996) 21898-21905.

[32] G.V. Putcha, M. Deshmukh, E.M. Johnson Jr., BAX translocation is a critical event in neuronal apoptosis: regulation by neuroprotectants, BCL-2, and caspases, J. Neurosci. 19 (1999) 7476-7485.

[33] G.V. Putcha, K.L. Moulder, J.P. Golden, P. Bouillet, J.A. Adams, A. Strasser, E.M. Johnson, Induction of BIM, a proapoptotic BH3-only BCL-2 family member, is critical for neuronal apoptosis, Neuron 29 (2001) 615-628.

[34] B. Su, M. Karin, Mitogen-activated protein kinase cascades and regulation of gene expression, Curr. Opin. Immunol. 8 (1996) 402-411.

[35] K. Virdee, A.J. Bannister, S.P. Hunt, A.M. Tolkovsky, Comparison between the timing of JNK activation, c-Jun phosphorylation, and onset of death commitment in sympathetic neurones, J. Neurochem. 69 (1997) 550-561.

[36] A. Watson, A. Eilers, D. Lallemand, J. Kyriakis, L.L. Rubin, J. Ham, Phosphorylation of c-Jun is necessary for apoptosis induced by survival signal withdrawal in cerebellar granule neurons, J. Neurosci. 18 (1998) 751-762.

[37] J. Whitfield, S.J. Neame, L. Paquet, O. Bernard, J. Ham, Dominantnegative c-Jun promotes neuronal survival by reducing BIM expression and inhibiting mitochondrial cytochrome $c$ release, Neuron 29 (2001) 629-643.

[38] S. Willaime, P. Vanhoutte, J. Caboche, Y. Lemaigre-Dubreuil, J Mariani, B. Brugg, Ceramide-induced apoptosis in cortical neurons is mediated by an increase in p38 phosphorylation and not by the decrease in ERK phosphorylation, Eur. J. Neurosci. 13 (2001) 2037-2046.

[39] S. Willaime-Morawek, K. Brami-Cherrier, J. Mariani, J. Caboche, B. Brugg, JNK/c-Jun and p38 pathways cooperate in ceramide-induced neuronal apoptosis, Neuroscience 2003, in press.

[40] Z. Xia, M. Dickens, J. Raingeaud, R.J. Davis, M.E. Greenberg, Opposing effects of ERK and JNK-p38 MAP kinases on apoptosis, Science 270 (1995) 1326-1331.

[41] S. Zhuang, J.T. Demirs, I.E. Kochevar, p38 mitogen-activated protein kinase mediates bid cleavage, mitochondrial dysfunction, and caspase- 3 activation during apoptosis induced by singlet oxygen but not by hydrogen peroxide, J. Biol. Chem. 275 (2000) 25939 25948 . 